\title{
REPRESENTASI SEJARAH INDONESIA DALAM NOVEL-NOVEL KARYA AYU UTAMI
}

\author{
Wiyatmi \\ FBS UniversitasNegeri Yogyakarta \\ email: wiyatmi_fbs@yahoo.com
}

\begin{abstract}
Abstrak
Penelitian ini bertujuan mendeskripsikan wujud dan representasi peristiwa sejarah sosial politik dalam novel-novel karya Ayu Utami. Untuk mencapai tujuan tersebut diteliti empat buah novel karya Ayu Utami, yaitu Saman, Larung, Manjali dan Cakrabirawa, dan Cerita Cinta Enrico dengan menggunakan perspektif New Historicism. Hasil penelitian sebagai berikut. Pertama, peristiwa sejarah sosial politik yang terdapat dalam novel-novel karya Ayu Utami adalah: (a) peristiwa di Medan 1 Maret sampai dengan 16 April 1994, (b) Gerakan 30 September 1965, (c) tragedi 27 Juli 1996 di Jakarta, (d) pemberontakan Pemerintahan Revolusioner Republik Indonesia (PRRI), 15 Februari 1958 di Padang, (e) demonstrasi Mahasiswa ITB dan penerbitan Buku Putih Perjuangan Mahasiswa 1978. Kedua, peristiwa-peristiwa tersebut direpresentansikan dalam bagian yang integral dengan peristiwa yang dialami oleh tokoh-tokoh dalam novel. Peristiwa sejarah yang berasal dari peristiwa nyata dikontekstualkan dalam novel. Dalam perspektif New Historicism, peristiwa sejarah sosial politik dihadirkan untuk mempertanyakan kembali kebenaran sejarah yang telah dicatat sebelumnya.
\end{abstract}

Kata kunci: representasi, sejarah, sosial politik, New Historicism

\section{THE REPRESENTATION OF THE INDONESIAN HISTORY IN AYU UTAMI'S NOVELS}

\begin{abstract}
This study aims to describe the form and representation of socio-political historical events in Ayu Utami's novels. The data sources were four novels written by Ayu Utami, namely Saman, Larung, Manjali dan Cakrabirawa, and Cerita Cinta Enrico. They were analyzed using the New Historicism perspective. The findings are as follows. First, socio-political historical events in the novels are: (a) an event in Medan from 1 March to 16 April 1994, (b) 30 September Movement in 1965, (c) the tragedy of 27 July 1996 in Jakarta, (d)the rebellion by the Republic of Indonesia's Revolutionary Government, 15 February 1958 in Padang, (e)the demonstration by students of Technology Institute of Bandung and the publication of the Student Struggle White Book in 1978. Second, the events are represented in parts integrated into the events that the characters experience. Historical events from factual events are contextualized in the novels. In the New Historicism perspective, socio-political historical events are presented to question historical truths previously recorded.
\end{abstract}

Keywords: representation, history, socio-political, New Historicism

\section{PENDAHULUAN}

Penciptaan karya sastra tidak pernah terlepas dari kondisi sosial historis masyarakat yang melahirkannya. Karya sastra ditulis oleh pengarang, yang merupakan anggota masyarakat, berdasarkan keadaan realitas yang terjadi di masyarakat. Karya sastra lahir sebagai pencatat, dokumen, bahkan juga melakukan evaluasi terhadap realitas yang terjadi dalam masyarakat (Damono, 1989). Sejumlah karya sastra Indonesia telah menunjukkan adanya hubungan yang tak terpisahkan antara isi (muatan) karya 
dengan realitas yang terjadi dalam masyarakatnya. Novel Sitti Nurbaya (Rusli, 1920), misalnya menggambarkan kembali keadaan masyarakat Minangkabau pada masa kolonial Belanda. Novel Para Priyayi (Kayam, 1999), menggambarkan keadaan masyarakat Jawa pada masa kolonial Belanda sampai awal Orde Baru. Novel Saman (Utami, 1998), menggambarkan keadaan masyarakat Indonesia pada akhir pemerintahan Orde Baru.

Adanya hubungan antara karya sastra dengan realitas yang terjadi dalam masyarakat, seperti dicontohkan dalam ketiga novel tersebut, menunjukkan bahwa untuk memahami karya sastra diperlukan kajian yang melibatkan hubungan antara karya sastra dengan segi-segi kemasyarakatan. Dengan memahami karya sastra dalam hubungannya dengan realitas sosial, budaya, dan politik yang terjadi dalam masyarakat, tidak mustahil seorang pembaca sastra akan menemukan kembali realitas sejarah yang digambarkan dalam karya sastra. Dalam hal ini, realitas sejarah, khususnya yang berhubungan dengan peristiwa masa lampau, tidak hanya ditemukan dalam teks-teks sejarah, tetapi juga dalam karya sastra, misalnya novel. Berdasarkan pembacaan awal terhadap sejumlah novel Indonesia, dapat ditemukan sejumlah novel yang menggambarkan kembali peristiwa sejarah yang pernah terjadi di Indonesia.

Peristiwa sejarah merupakan salah satu sumber inspirasi yang cukup menarik bagi sejumlah sastrawan, sehingga mereka kemudian menuliskannya kembali ke dalam karya-karya. Salah satu sastrawan yang banyak memanfaatkan peristiwa sejarah Indonesia dalam penulisan novelnovelnya adalah Ayu Utami. Empat buah novelnya, Saman (1998), Larung (2001), Manjali dan Cakrabirawa (2010), serta Cerita Cinta Enrico (2012) kesemuanya mengambil peristiwa sejarah sebagai bagian dari cerita yang ditulisnya. Beberapa peristiwa sejarah yang dapat dikenali kembali da- lam novel-novel tersebut antara lain adalah peristiwa pemberontakan 30 September 1965, kerusuhan Juli 1998 di Jakarta, dan peristiwa PRRI di Padang. Peristiwa sejarah dalam novel-novel tersebut terjalin dalam cerita karena menjadi bagian dari para tokoh novel. Bahkan, dapat dikatakan bahwa novel-novel tersebut ditulis untuk memahami dan mereinterpretasikan sejumlah peristiwa sejarah Indonesia.

Berdasarkan latar belakang tersebut, penelitian ini memfokuskan kajian pada representasi sejarah Indonesia dalam novel-novel Karya Ayu Utami. Masalah tersebut akan dipahami dengan pendekatan new historicism. Pilihan terhadap pendekatan tersebut dilatarbelakangi oleh adanya karakteristik novel-novel karya Ayu Utami yang cenderung merepresentasikan peristiwa-peristiwa sejarah Indonesia dalam warna yang berbeda dengan teks-teks sejarah pada umumnya. Berbagai peristiwa sejarah, seperti pemberontakan/gerakan 30 September 1965 dan kerusuhan Mei 1998 di Jakarta direpresentasikan secara berbeda dengan yang digambarkan dalam buku-buku sejarah. Dengan demikian, novel-novel tersebut diduga mempertanyakan pandangan secara konvensional terhadap peristiwa-peristiwa sejarah sosial politik yang ada.

\section{METODE}

Masalah representasi peristiwa sejarah sosial politik dalam novel-novel karya Ayu Utami dipahami dengan menggunakan penelitian kualitatif interpretif dengan pendekatan pembacaan paralel antara teks sastra yang merepresentasikan peristiwa sejarah dengan teks sejarah yang menggambarkan peristiwa yang sama. Dalam penelitian ini metode tersebut digunakan untuk mendeskripsikan dan menginterpretasikan representasi peristiwa sejarah sosial politik dalam novelnovel karya Ayu Utami. 
Sumber data penelitian adalah empat buah novelnya, Saman (1998), Larung (2001), Manjali dan Cakrabirawa (2010), serta Cerita Cinta Enrico (2012) dan bukubuku sejarah Indonesia yang membicarakan peristiwa sejarah sosial politikyang digambarkan dalam keempat novel tersebut. Data berupa kata, frase, kalimat, dan satuan cerita diambil dari novel yang menjadi objek penelitian dan buku-buku sejarah, yang mengandung informasi yang berkaitan dengan masalah penelitian. Di samping itu juga dikumpulkan data yang berhubungan dengan informasi yang berhubungan dengan representasi peristiwa sejarah dalam novel-novel karya Ayu Utami. Data tersebut dicatat dalam kartu data dan diklasifikasikan sesuai dengan informasi yang berhubungan dengan masalah yang diteliti.

Analisis data dilakukan dengan teknik deskriptif kualitatif melalui kegiatan kategorisasi, tabulasi, dan inferensi. Kategorisasi digunakan untuk mengelompokkan data berdasarkan kategori yang telah ditetapkan. Tabulasi digunakan untuk merangkum keseluruhan data dalam bentuk tabel. Inferensi digunakan untuk menginterpretasikan dan menyimpulkan hasil penelitian sesuai dengan permasalahan penelitian. Dalam penelitian ini inferensi didasarkan pada kerangka teori dan pendekatan new historicism (Budianta, 2006:4).

Sesuai dengan cara kerja new historicism, data-data dalam penelitian ini diinterpretasikan dengan langkah sebagai berikut. Pertama, memahami femomena sejarah dalam teks sastra dan teks sejarah. Kedua, memfokuskan perhatian baik pada teks sastra dan teks sejarah pada isu kekuasaan negara dan cara melestarikannya, pada struktur patriarki dan pemeliharaannya, dan pada proses kolonialisasi dengan "mind-set" yang mengikutinya. Ketiga, menggunakan cara berpikir postrukturalisis, dengan memahami setiap segi realitas tertuang dalam teks (dalam konsep Derrida) dan struktur sosial yang ditentukan oleh "praktik diskursif" yang dominan (dalam konsep Foucault) (Barry, 2010:209).

Dalam penelitian ini validitas data yang digunakan adalah validitas semantik. Makna sesuai dengan konteksnya. Sementara reliabilitas menggunakan pembacaan berulang-ulang (intraratter) sehingga ditemukan konsistensi data dan interpretasi data.

\section{HASIL DAN PEMBAHASAN}

Peristiwa sejarah sosial politik yang terdapat dalam novel-novel Ayu Utami adalah (1) demontrasi dan pemogokan buruh di Medan 1 Maret 1994 sampai dengan 16 April 1994, (2) peristiwa Gerakan 30 September 1965 di Jakarta, (3) tragedi 27 Juli 1996 di Jakarta, (4) Peristiwa PRRI di Padang 15 Februari 1958, dan (5) demonstrasi mahasiswa ITB pengangkatan kembali Soeharto sebagai Presiden RI. Peristiwa-peristiwa tersebut direpresentasikan oleh Ayu Utami dalam empat buah novelnya, yaitu Saman, Larung, Manjali dan Cakrabirawa, dan Cerita Cinta Enrico. Melalui keempat novelnya tersebut tampak adanya representasi yang mencoba mempertanyakan kebenaran pencatatan peristiwa-peristiwa tersebut dalam teksteks sejarah yang ada selama ini (sejarah konvensional), terutama yang diakui kebenarannya oleh pemerintah (penguasa) Orde Baru.

\section{Demonstrasi dan Pemogokan Buruh di Medan 1 Maret sampai dengan 16 April 1994}

Demonstrasi pemogokan buruh yang terjadi di Medan dari tanggal 1 Maret sampai 16 April 1994 direpresentasikan dalam novel Saman, terutama dalam hubungannya dengan tokoh Wisangeni (Saman). Dalam novel tersebut Saman dituduh terlibat sebagai aktor intelektual demontrasi buruh besar-besaran di Medan pada bulan April 1994. Dia menjadi salah 
seorang yang masuk dalam daftar orang yang paling banyak dicari oleh aparat pemerintah. Namun, atas pertolongan Yasmin, dia berhasil diselamatkan dengan melarikan diri ke Amerika.

Peristiwa demonstrasi dan pemogokan buruh besar-besaran yang terjadi di Medan 1994 dalam novel Saman digunakan untuk memberi konteks cerita yang menyebabkan Saman menjadi salah satu tokoh yang dikejar-kejar oleh aparat keamanan. Melalui peristiwa yang dialami oleh Saman novel ini mencoba memaknai dan memberikan tanggapannya terhadap peristiwa sejarah tersebut.

Dari arsip data di hamline.edu/apakabar/basisdata/1994/05/05/0002 dapat diperoleh informasi bahwa antara tanggal 1 Maret 1994 sampai dengan 16 April 1994, terjadi demontrasi dan pemogokan buruh besar-besaran di Medan, melibatkan 26.000 buruh. Demontrasi yang semula bertujuan menuntut kenaikan gajidan THR tersebut berkembang menjadi demonstrasi anti keturunan Cina dan menyebabkan terbunuhnya seorang pengusaha Kwok Joe Lip alias Yuli Kristanto. Setelah peristiwa tersebut pada 2 Mei ketua SBSI (Serikat Buruh Seluruh Indonesia) cabang Medan Amosi Telaumbanua bersama wakil ketua dan sekretaris DPC Soniman Lafao dan Fatiwanalo Zega diperiksa di Mapoltabes Medan sebagai tersangka dalam kasus unjuk rasa buruh dan perusahaan di kota itu (Suara Pembaruan, Senin 2 Mei 1994).

Dalam Saman peristiwa tersebut digambarkan melalui surat Saman yang dikirimkan kepada Yasmin sebagai berikut.

Sekarang bagaimana keadaan di tanah air, terutama Medan? Aku baru mulai memeriksa laporan dan file tentang unjuk rasa yang rusuh dua pekan lalu itu, yang akhirnya membikin aku terdampar di sini. Nampaknya banyak orang tidak begitu faham apa yang terjadi dan menjadi canggung untuk bersikap. Demonstrasi buruh yang diikuti enam ribu orang sebetulnya adalah hal yang simpatik dan luar biasa untuk ukuran Indonesia di mana aparat selalu terserang okhlosofobia -cemas setiap kali melihat kerumunan manusia. Namun, simpati orang segera berbalik setelah unjuk rasa itu menampilkan wajah rasis dan memakan korban. Aku amat sedih dan menyesali kematian pengusaha Cina itu...(hal:168)

Dalam novel tersebut diceritakan bahwa sebagai aktivis yang memiliki hubungan dengan Serikat Buruh Seluruh Indonesia (SBSI), Saman dianggap sebagai salah satu aktor intelektual danmasuk dalam daftar pencarian orang. Para aktivis yang ditangkap dalam aksi-aksi sosial di Indonesia pada masa Orde Baru diadili di pengadilan militer, prosesnya tertutup, tidak transparan, dan tidak mengakomodasi kepentingan korban. Akibatnya, pelaku yang diadili hanyalah pelaku lapangan, hukuman rendah sementara kebenaran tidak terungkap. Di samping itu, hak-hak korban juga tak kunjung dipenuhi. Oleh karenaitu, untukmenghindarkanSamanyang dituduh sebagai aktor intelektual demonstrasi buruh di Medan 1994-dari sistem peradilan militer yang melanggar hak azasi manusia tersebut, Yasmin yang memiliki hubungan dengan Human Rights Watch menolong Saman untuk melarikan diri ke luar dari Indonesia. Perjuangan Yasmin dalam menyelamatkan Saman tampak dari catatan harian yang ditulis oleh Saman yang dikirimkan kepada Yasmin, misalnya pada kutipan berikut.

18 April - Menurut lobi ayahnya di kepolisian Jakarta, aku termasuk lima orang yang paling diburu. Ia membujukku untuk melarikan diri ke luar negeri. Katanya, itu bukan pendapatnya sendiri, melainkan kesepakatan kawan-kawan yang lain. Kebetulan Human Rights Watch butuh seseorang untuk membuat jaringan informasi di Asia Tenggara.

Dari kutipan tersebut tampak bahwa Wisanggeni (Saman) yang namanya 
masuk dalam daftar pencarian orang yang harus "diamankan" pada masa Orde Baru ditolong oleh Yasmin dan kawan-kawannya untuk keluar dari Indonesia. Dengan kecerdasan dan koneksinya, Yasmin memiliki peran yang cukup besar untuk menyelamatkan Saman dari target operasi keamanan pemerintah Orde Baru. Yasmin, bahkan telah mempersiapkan dengan rapi strategi dan penyamaran Saman agar berhasil berangkat ke Amerika.

Kini Yasmin telah mengurus segalanya agar aku pergi dari Indonesia. Dan ternyata mereka mendandaniku dengan serius, menempel kumis palsu, mencukur rambutku, dan mencabuti alisku agar bentuknya berubah. Lalu mereka mencocok-cocokkan wajahku dengan foto pada sebuah KTP, kartu identitas salah seorang pesuruh Cok di sebuah hotelnya di Pekanbaru. Yasmin memang telah menyiapkan segala hal dengan rapih seperti ia biasa bekerja. (hal:175)

Dari pembahasan tersebut tampak digambarkan peristiwa sejarah masa Orde Baru, khsususnya demonstrasi dan pemogokan buruh di Medan 1 Maret 1994 sampai dengan 16 April 1994, yang diintegrasikan dalam cerita novel $\mathrm{Sa}$ man. Dengan menggambarkan peristiwa tersebut dapat dikatakan bahwa Saman merepresentasikan represi kekuasaan Orde Baru terhadap para buruh yang berdemonstrasi dan menuntut kenaikan gaji dan tunjangan hari raya (THR).

\section{Peristiwa Gerakan 30 September 1965}

Peristiwa Gerakan 30 September 1965 digambarkan dalam novel Larung dan Manjali dan Cakrabirawa. Dalam Larung peristiwa Gerakan 30 September 1965 digambarkan dalam kenangan nenek Adnjani (nenek Larung) ketika mengenang anak laki-lakinya yang dituduh terlibat PKI pada suatu hari ditangkap dan disiksa oleh aparat (TNI).

Setahun kemudian, 1965, kau melihat seperti barisan yang sama, kali ini lebih besar jumlahnya menuju rumah kita. Kau tidak menyadari waktu tetapi aku mencatat tanggal itu: 21 November. Kau tidak mengerti apa yang terjadi, tetapi aku menggores semua itu dalam urat-urat jantungku. Mereka datang mengambil anakku, tanpa mengetuk pintu. Sebab sebelum mereka menyentuh daunnya, aku telah berdiri di sana. Telah kudengar sebelumnya, bisik-bisik orang menuduhku menyimpan ular di lipatan stagen. Nenek itu leak, rangda dengan sad tatayi...

... Apa kesalahannya, tak ada lagi orang yang bertanya. Sebab ia dikenal semua tentara di kompleks kita, sebab ia datang dari rumah ke rumah mengurusi perdagangan beras subsidi. Maka ketika para perwira harus menyebut orang-orang dalam pasukan yang terlibat dalam kudeta 30 September, semua menyebut namanya. (hal:68-69)

Kutipan tersebut menunjukkan bahwa ayah Larung, seorang anggota TNI yang tinggal di Bali pada bulan November ditangkap oleh aparat Orde Baru karena dianggap sebagai anggota Partai Komunis Indonesia (PKI) dan terlibat dalam kudeta 30 September di Jakarta. Pemerintahan Orde Baru yang dipimpin oleh Presiden Soeharto menganggap bahwa peristiwa pembunuhan para jenderal di Jakarta 30 September 1965 didalangi oleh PKI. Oleh karena itu, partai tersebut dibekukan dan orang-orang yang dianggap sebagai anggota PKI harus dihukum.

Penangkapan dan pembunuhan ayah Larung pada bulan November 1965 merupakan rangkaian dari upaya menumpas PKI karena dianggap sebagai dalam peristiwa G30S, yang mengarah kepada kudeta terhadap pemerintahan saatitu. Keterlibatan PKI dan pasukan Cakrabirawa dalam G30S dikaitkan dengan isi Tajuk Rencana di Harian Rakyat, 2 Oktober 1965.

Gerakan 30 September

Bahwa tanggal 30 September tindakantindakan telah diambil untuk menyelamatkan Presiden Soekarno dan Republik 
Indonesia dari sebuah Coup oleh apa yang disebut dengan Dewan Jendral. Sesuai pengumuman Gerakan 30 September yang dipimpin oleh Letnan Kolonel Untung dari Batalyon Cakrabiwara, tindakan diambil untuk menyelamatkan Presiden Soekarno dan Republik Indonesia dari kup Dewan Jendral patriotik dan revolusioner. Apapun alasannya yang digunakan Dewan Jendral dalam upayanya pelaksanaan kudeta merupakan tindakan yang terkutuk dan tindakan kontra revolusi.

(Luhulima, 2007: 122).

Dengan isi tajuk rencana tersebut, yang secara terang-terangan mendukung G30S yang jelas-jelas sudah gagal, maka PKI dianggap mendalangi G30S. Isi tajuk rencana tersebutlah yang dijadikan bukti awal keterlibatan PKI dalam G30S (Luhulima, 2007:33). Selain itu, karena Letnan Kolonel Untung, sebagai Komandan Batalyon Cakrabirawa, memimpin gerakan tersebut. Oleh karena itu, keterlibatan Cakrabirawa tidak dapat dipungkiri. Hal ini sesuai dengan warta berita Radio Republik Indonesia (RRI) pada tanggal 1 Oktober 1965, pukul 07.15.

Pada hari Kamis tanggal 30 September 1965 di Ibu Kota Republik Indonesia, Jakarta telah terjadi gerakan militer dalam Angkatan Darat yang dibantu oleh pasukan-pasukan dari angkatan bersenjata lainnya.

Gerakan 30 September yang dikepalai oleh Letnan Kolonel Untung Komandan Batalyon Cakrabirawa, pasukan pengawal pribadi Presiden Soekarno ini ditujukan kepada jendral-jendral anggota apa yang dinamakan dirinya Dewan Jendral. Sejumlah jendral telah ditangkap dan alat lomunikasi yang penting-penting serta objek-objek vital lainnya sudah berada dalam kekuasaan Gerakan 30 September, sedangkan Presiden Soekarno selamat dalam lindungan Gerakan 30 September... (Luhulima, 2007:90).

Karena berita tersebut merupakan versi resmi pemerintah, yang kemudian kemudian dipertegas dengan Surat Kepu- tusan Presiden Nomor 1/3/1966 tanggal 12 Maret 1966 tentang pembubaran PKI di seluruh Indonesia, maka anggapan bahwa PKI merupakan dalang dalam peristiwa G30S diyakini sebagai kebenarannya secara umum (Luhulima, 2007:16; 23).

Selain versi resmi pemerintah telah banyak versi lain mengenai peristiwa G30S. Dalam sejarah Indonesia peristiwa gerakan 30 September 1965 menyebabkan terbunuhnya sejumlah tokoh yaitu (1) Jenderal TNI Ahmad Yani, (2) Letjend TNI R. Suprapto, (3) Letjend TNI M.T. Haryono, (4) Letjend TNI S. Parman, (5) Mayjend TNI D.I. Panjaitan, (6) Mayjend TNI Sutoyo Siswomiharjo, (7) Ajun Inspektor Polisi Dua K.S. Tubun, (8) Brigjend Katamso D., (9) Kol. R. Sugiyono, (10) Ade Irma Suryani Nasition. Mengenai peristiwa tersebut terdapat sejumlah kontroversi tentang siapa sebenarnya yang bertanggung jawab terhadap terjadinya peristiwa tersebut. Buku-buku sejarah versi resmi pemerintah Orde Baru menyebutkan bahwa peristiwa tersebut didalangi oleh PKI, Angkatan Udara Republik Indonesia (AURI), bahkan pangkalan udara Halim Perdana Kusuma dianggap sebagai markas G30S (Luhulima, 2007:5).

Versi semacam itu juga dapat dibaca dalam Sejarah Indonesia Modern, Ricklefs (1991:427-428). Menurut Ricklefs (1991:426-427) tampaknya mustahil untuk mempercayai bahwa hanya ada satu dalang yang mengendalikan semua peristiwa itu, dan tafsiran-tafsiran yang berusaha mejelaskan kejadian-kejadian tersebut harus dipertimbangkan secara hati-hati. Menurutnya, situasinya pada saat itu adalah sebagai berikut.

Pada tanggal 30 September malam itu satu batalyon pengawal istana yang dipimpin oleh Letnan Kolonel Untung (sebelumnya dari Divisi Diponegoro), satu batalyon lagi dari Divisi Diponegoro, satu batalyon dari Divisi Brawijaya, dan orang-orang sipil dari Pemuda Rakyat PKI meninggalkan pangkalan udara Halim. Mereka pergi untuk menculik Nasution, Yani, Parman, 
dan empat orang jenderal senior angkatan darat lainnya dari rumah-rumah mereka di Jakarta. Pemimpin-pemimpin usaha kudeta tersebut termasuk Brigadir jenderal Supardjo dari Divisi Siliwangi dan kepala intelijen Divisi Diponegoro. Untung tampaknya hanya menjadi sebuah pion. Mereka mendapat dukungan dari Omar Dhani, yang telah memberikan pangkalan udara Halim sebagai markas besar mereka dan dia sendiri hadir di sana. Mereka juga menjalin hubungan dengan Biro Khusus PKI Sjam dan beberapa orang Politbiro PKI, setidak-tidaknya secara samar-samar mengetahui rencana-rencana mereka. Anggota-anggota Gerwani dan Pemuda Rakyat ikut ambil bagian dalam pembunuhan-pembunuhan tersebut. (Ricklefs, 1991:427).

Peristiwa tersebut tetap menjadi misteri hingga saat ini. Berbagai interpretasi pun bermunculan mengenainya. Menurut Luhulima (2007:1), yang mencoba melihat peristiwa G30S dari perspektif yang berbeda dengan versi resmi pemerintah Orde Baru, ada tujuh versi tentang siapa dalang di balik peristiwa G30S tersebut, yaitu (1) Partai Komunis Indonesia (PKI), (2) sebuah klik di dalam Angkatan Darat sendiri, (3) Badan Pusat Intelijen Amerika Serikat (CIA/Pemerintah Amerika Serikat), (4) rencana Inggris yang bertemu dengan rencana CIA, (5) Presiden Sukarno, (6) Panglima Komando Cadangan Strategis Angkatan Darat (Kostrad) Mayor Jenderal Soeharto, (7) tidak ada dalang tunggal karena semua pihak yang terkait dalam peristiwa itu hanya beraksi sesuai dengan prekembangan yang terjadi dari waktu ke waktu.

Gambaran mengenai apa sebenarnya yang terjadi menjelang peristiwa G30S dan bagaimana posisi PKI, Cakrabirawa, dan AURI dalam peristiwa tersebut mulai terungkap setelah berakhirnya pemerintahan Orde Baru dan kekuasaan Soeharto. Karena Angkatan Udara Republik Indonesia (AURI), bahkan pangkalan udara Halim Perdana Kusuma dianggap sebagai markas G30S), maka pada tanggal 13 Oktober 1998 sejumlah purnawirawan AURI di bawah pimpinan Laksda Udara (Purn) Sri Mulyono Herlambang mengadakan jumpa pers guna mengungkapkan niat mereka untuk meluruskan sejarah (Luhulima, 2007:33), yang disusul dengan penerbitan buku Menyingkap Kabut Halim 1965 (Katoppo, dkk., 1999). Pada intinya buku tersebut berisi penjelasan bahwa AURI secara institusi tidak terlibat dalam Gerakan G30S, meskipun tidak mengingkari adanya anggota AURI yang terlibat (Luhulima, 2007:35). Dari buku Menyingkap Kabut Halim 1965 itu diketahui bahwa Desa Lubang Buaya yang dijadikan markas pusat G30S itu terletak di luar wilayah PAU Halim Perdanakusuma. Desa tersebut berjarak sekitar satu kilometer dari Lubang Buaya dropping zone, tempat latihan terjun payung yang terletak di dalam wilayah Halim Perdanakusuma. Oleh karena itu, penyebutan bahwa Pangkalan Angkatan Udara Halim Perdanakusuma merupakan markas pusat G30S adalah keliru (Luhulima, 2007:34).

Selanjutnya, mengenai tuduhan keterlibatan PKI (yang diketuai oleh DN. Aidit), Omar Dani (Men/Pangau), dan Soekarno karena ketiganya pada malam 30 September 1965 berada di Halim Perdanakusuma dalam buku Menyingkap Kabut Halim 1965 dijelaskan sebagai berikut.

Kehadiran Ketua PKI DN Aidit, Men/Pangau Laksdya Udara Omar, dan Presiden Soekarno di PAU Halim Perdanakusuma hanyalah suatu kebetulan belaka. Ketiganya berada di PAU Halim Perdanakusuma dengan alasan yang berbeda-beda.

DN Aidit berada di kawasan PAU Halim Perdanakusumakarena dijemputdi rumahnya dan disembunyikan oleh Mayor Udara Sujono. Sementara Omar Dani menginap di Markas Komando Operasi Angkatan Udata atas saran Panglima Koops AU Komodor Udara Leo Wattimena. Tanggal 30 September 1965 malam, setelah mendengar informasi dari Asisten Direktur Intelijen Angkatan Udata Letkol (Pnb) 
Heru Atmodjo bahwa perwira-perwira muda, terutama dari Angkatan Darat akan dijemput paksa para jenderal Angkatan Darat yang akan mengadakan kudeta terhadap Presiden Soekarno, Panglima Koops AU Komodor Udara Leo Wattimena menyarankan agar Men/Pangau Laksdya Udara Omar Dani sebaiknya berada dan beristirahat di Markas Koops AU. Menurut Leo Wattimena, yang merasa paling bertanggung jawab atas keamanan dan keselamatan Men/Pangau, di Markas Koops AU keamanan Laksdya Udara Omar lebih terjamin, sedangkan Presiden Sorkarno atas keinginannya sendiri memutuskan untuk pergi ke PAU Halim Perdanakusuma karena menilai keadaan pada tanggal 1 Oktober 1965 pagi sangat tidak menentu, Presiden Soekarno mengganggap yang terbaik bagi keamanan dirinya adalah berada di PAU Halim Perdanakusuma. Mengingat PAU Halim Perdanakusuma ada pesawat udara yang dapat membawanya setiap saat ke tempat lain, kalau terjadi sesuatu yang tidak diharapkan. Penyebutan PAU Halim Perdanakusuma sebagai markas pusat G30S membuat Ketua PKI DN Aidit, Men/Pangau Laksdya Udara Omar Dani, dan Presiden Soekarno di sana pada waktu yang bersamaan menjadi serba salah. (Luhulima, 2007:36-37)

Penangkapan dan pembunuhan Aidit tersebut terungkap dari wawancara Yasir Hadibroto yang dimuat di Kompas Minggu 5 Oktober 1980. Setelah dibawa ke Loji Gandrung, Aidit diminta untuk menuliskan pengalamannya sebelum dan langkah yang akan dilakukannya seandainya ia tidak tertangkap. Namun, karena setelah ditunggu sekitar satu jam, Aidit diam saja, sambil merenung dan merokok, maka Kolonel Yasir berinisiatif lain. Mayor Sugeng diperintahkan untuk menuliskan apa yang diucapkan Aidit. Hal yang dituliskan oleh Mayor Sugeng adalah pengakuan bawa Aidit adalah satu-satunya yang memikul tanggung jawab paling besar dalam peristiwa G30S/ PKI yang didukung oleh para anggota
PKI lain dan organisasi-organisasi massa di bawah PKI. Dia merencanakan untuk menghimpun kekuatan komunis di Jawa Tengah. Namun, pengakuan yang ditandatangani oleh Aidit tersebut diberikan di bawah todongan senjata. Selanjutnya di tengah perjalanan, Aidit ditembak mati oleh Yasir (Luhulima, 2007:38). Keputusan membunuh tersebut diambil oleh Yasir karena dia sebelumnya mendapatkan perintah dari Mayjen Soeharto:

Orang-orang yang memberontak saat ini adalah anak-anak PKI Madiun dulu. Sekarang bereskan itu semua. DN Aidit ada di Jawa Tengah, bawa pasukanmu ke sana. (Luhulima, 2007: 39)

Melalui suara nenek Larung (Adnjani) novel Larung meragukan keterlibatan orang-orang yang ditangkap, dibunuh, dan dihukum karena dianggap sebagai anggota PKI. Di samping itu, juga dipertanyakan keterlibatan PKI dalam peristiwa 30 September 1965. Keraguan tersebut tampak pada data berikut ini.

Mereka memfitnahnya, kata ibumu. Tidak, kataku. Sebab hidup adalah pilihan semena. Suamimu, anakku itu, barangkali bukan komunis, partai komunis barangkali tidak kudeta, tetapi apa arti semua itu? Orang-orang harus menunjuk orang lain untuk menyelamatkan diri.... (hal:68-69)

Setelah ayah Larung dianggap sebagai anggota PKI yang terlibat dalam peristiwa 30 September 1965, ibu Larung pun dituduh sebagai anggota Gerwani.

Lalu aku mendengar, orang-orang menyebut ibumu gerwani. Ibumu memakai beha hitam dengan lambang bintang merah di satu pucuknya, palu arit di pucuk yang lain, kata mereka. Ia mengumpulkan perempuan-perempuan dan mengajar tari telanjang, dan mengirim wanitawanita untuk merayu para prajurit dengan pinggul mereka agar percaya pada komunisme, bukan pada segala Tuhan. Sembari bernyanyi genjer-genjer. Tetapi aku tahu ibumu dan istri Nyoman Pintar 
kerap berada di bangsal dan mengajari sesama istri tentara membikin ketupat dan janur dari daun nyiur. Mereka semua pendatang. Dan daun genjer hanyalah sayuran yang membuat tinjamu lengket panjang.... (hal:70)

Dari kutipan tersebut tampak bahwa Ibu Larung memang sering berkumpul bersama-sama para perempuan pendatang (istri para prajurit) untuk mengajari membuat ketupat dan janur dari daun nyiur yang digunakan untuk perlengkapan upacara di Pura. Namun orang-orang mengatakan (memfitnah) bahwa kegiatan ibu Larung bersama ibu-ibu adalah mengajar tari telanjang dan mengirim wanita-wanita untuk merayu para prajurit dengan pinggul mereka agar percaya pada komunisme.

Peristiwa Gerakan 30 September dalam novel Manjali dan Cakrabirawa digambarkan dalam cerita yang berhubungan dengan tokoh Musa Wanara, seorang prajurit TNI-ABRI yang bertemu dengan Yuda dalam latihan bersama panjat tebing. Musa Wanara adalah anak seorang anggota pasukan Cakrabirawa, pengawal Presiden Soekarno, yang dalam peristiwa gerakan 30 September 1965 dianggap ikut bertangung jawab terhadap pembunuhan para jenderal.

"Musa," panggilnya dengan nada bersahabat. "Kamu menyimpan lambang Cakrabirawa di dompet. Kamu tidak takut dianggap simpatisan PKI?"

Seorang prajurit TNI-ABRI tidak mungkin seorang pemuja PKI sekaligus.

Pemerintahan Jendral Soeharto bermula dari penumpasan partai komunis pada tahun 1965. Dalam bahasa Parang Jati: rezim militer itu berdiri di genangan darah lebih dari sejuta orang yang dituduh komunis. Bersama dengan itu segala unsur komunisme dilarang di negeri ini. Sampai hari ini istilah "bersih lingkungan" diperkenalkan...

"Kamu tidak khawatir dompetmu ditemukan orang lain? Komandan, misalnya?" Ia memberi nada simpati.
"Tidak," jawab Musa lebih yakin. "Sebab saya anti komunis seratus empat puluh persen." Ia tertawa. "Haha. Seratus itu angka penuh, empat puluh itu angka keramat. Jika saya bertemu dengan pengikut komunis, saya gebug dia! Saya tumpas! Kesetiaan saya pada NKRI!" Negara Kesatuan Republik Indonesia.

"Lalu kenapa kamu menyimpan lambang itu di dompet?"

Dengan kilat mata polos hewaninya Musa memberi jawab yang tak Yuda duga.

"Karena Cakrabirawa adalah mantra sakti! Karena tak ada hubungan antara Cakrabirawa dengan komuniske! Tak ada urusannya Cakrabirawa dengan PKI!"

Bagaimana mungkin? Yuda mengernyitkan dahi tanpa bersuara.

Bagi Musa, "Cakrabirawa” adalah mantra. Nama yang sakti pada dirinya sendiri. Cakrabirawa bukan milik Untung atau siapa pun komandan dan anggota pengawal Presiden Soekarno, sekalipun nama resimen itu adalah Cakrabirawa. (hal:75)

Dalam novel Manjali dan Cakrabirawa diceritakan bahwa Musa Wanara adalah anak dari pasangan Sarwengi, anggota pasukan Cakrabirawa dengan Murni, aktivis Gerwani (Utami, 2010:149). Pasca peristiwa G30S, ketika PKI, Gerwani, Cakrabirawa dianggap sebagai dalang peristiwa tersebut, maka Sarwegi pun dibunuh, sementara Murni dipenjara di Plantungan dan melahirnya bayi laki-laki di penjara. Bayi tersebut dipeliraha oleh Haji Samadiman, sahabat suaminya, dan diberi nama Musa Wanara. Cerita tentang asal-usul tokoh Musa terungkap setelah perkenalan antara tokoh Parang Jati dan Marja dengan Murni, seorang ibu tua yang tinggal sendirian di hutan. Parang Jati dan Marja, bersama seorang arkeolog, Jacques terlibat dalam sebuah penelitian mengenai situs Candi Calwanarang di Jawa Timur. Di tengah jalan tokoh Marja dan Parang Jati berkenalan dengan Murni, yang menggungkapkan cerita tentang Gerwani. Dengan menggambarkan tokoh Musa Wanara, ayah dan ibunya sebagai 
anggota pasukan Cakrabirawa dan Gerwani yang dibunuh dan mendapatkan penyiksaan karena dianggap terlibat G30S, novel tersebut jelas mencoba membertanyakan keterlibatan mereka dalam peristiwa tersebut.

\section{Tragedi 27 Juli 1996 di Jakarta}

Dalam novel Larung ditemukan peristiwa sejarah yang menggambarkan penyerangan kantor DPP Partai Demokrasi Pro Megawati oleh massa pendukung Suryadi yang terjadi tanggal 27 Juli 1996. Peristiwa tersebut disusul dengan kerusuhan yang mengakibatkan sejumlah bangunan instansi dan fasilitas umum di Jakarta dirusak dan dibakar massa.

Selain dipaparkan oleh narator dalam novel Larung, peristiwa tersebut juga disampaikan oleh Yasmin kepada Saman melalui email.

Sudah dua minggu aku meninggalkan kamu. Situasi politik di Jakarta semakin tegang. Telah satu bulan para pendukung Megawati bertahan di kantor PDI di jalan Diponegoro. Setiap hari ada orasi anti Orde Baru. Kini semua mendengar bahwa pemerintah akan memberi batas waktu. Mereka sedang menentukan tanggal untuk menyerbu. Dan aku berada di sekitar ketegangan ini. Aku merindukan kamu. (Email Yasmin untuk Saman, Utami, 2001:154).

Melalui emailnya kepada Saman, Yasmin mengabarkan situasi yang terjadi di Jakarta menjelang dan setelah peristiwa 27 Juli 1996. Di samping itu, narator juga menggambarkan bagaimana Larung yang tinggal di New York terus mengikuti berita politik di Jakarta melalui email dan kantor berita gelap karena pada saat itu banyak media massa yang dilarang terbit oleh pemerintah Orde Baru.

.... pagi ini delapan puluh enam pesan masuk dalam kotak suratnya. Sebagian polemik di Apakabar, Berita dari Pijar, Siar dan beberapa berkala dari kantor berita gelap lain yang bertambah aktif semenjak pemerintah membredel majalah Tempo, Editor, dan Detik dua tahun lalu. Gila begitu banyak yang terjadi selama dua tahun! -ia mengeluh, merasa tertinggal, tapi juga mengeluh karena suasana Indonesia yang makin represif. Ia mulai memeriksa surat-surat. (hal:167)

Paparan tentang peristiwa 27 Juli 1996, yang bersumber dari Siaran Pers (disusun oleh Institut Informasi Independen, pukul 21.30, dalam Larung adalah sebagai berikut.

Jakarta, 27 Juli 1996

PERISTIWA 27 JULI

Siaran Pers (disusun oleh Institut Informasi Independen, pukul 21.30)

Setelah lebih dari satu bulan para banteng proMegawati bertahan di kantor DPP PDI jalan Diponegoro 58 dan menggelar mimbar bebas, pasukan rezim Orde Baru akhirnya menyerbu.

Kronologi.

27 Juli, Sabtu pagi, sekitar pukul 06.00, sembilan truk serupa kendaraan sampah berwarna kuning berhenti di muka markas PDI dan menurunkan ratusan pemuda. Mereka mengenakan kaos merah bertuliskan Pendukung Kongres IV Medan -kongres yang menolak Megawati dan mengangkat Soerjadi sebagai ketua umum partai -dengan membawa batu serta pentung kayu sepanjang satu meter. Sebagian dari mereka berambut cepak dan berbadan tegap. Mereka langsung melempari kantor dan menyerang, sambil mencaci maki Megawati dan pendukungnya.

Beberapa saksi mata mengatakan, Komandan Kodim Jakarta Pusat Letkol. Zul Effendi terlihat berada di sana dan ikut mengatur menit-menit awal penyerbuan. Sepuluh menit kemudian sekitar 500 personil pasukan anti huru hara berseragam lengkap telah tiba. Kapolres jakarta Pusat Letkol. Abu Bakar bersama mereka. Pasukan membagi diri menjadi dua kelompok, dan menutup lokasi kejadian di ruas Megaria dan jalan Surabaya. Akibatnya pendukung Mega dari luar lokasi tak bisa memmberi bantuan. Di lokasi, penyerangan terhadap markas PDI terus berlangsung. Setelah lebih kurang sepuluh menit dua panser AD ditempatkan di bawah jembatan layang kereta api. 
Berita tentang penyerbuan telah beredar ke perkampungan sekitar sejak pagi. Masa yang marah dan ingin menonton membangkak di sekitar Megaria. Para pendukung Mega mengadakan mimbar bebas dan mencoba berunding dengar aparat untuk diperbolehkan melihat apa yang terjadi di kantor mereka. Suasana memanas.

Sekitar pukul 14.30 aparat membubarkan massa dengan pentung rotan. Massa melawan dengan lemparan batu. Terjadi perang antara massa dan petugas. Orang banyak yang marah membakar tiga bus di Salemba.

Pukul 15.00-20.30

Terjadi bola salju massa ke arah timur. Di jalan salemba, Kramat, dan Proklamasi beberapa gedung milik pemerintah serta swasta dibakar. Masing-masing adalah Gedung Persit Chandra Kirana, Ditjen Perikanan, Bank Swansarindo, Wisma Honda, Show Room Toyota, , ,',

(Utami, 2001:175)

Data tersebut memberikan gambaran mengenai situasi yang terjadi pada tanggal 27 Juli 1996 di Jakarta dan hari-hari setelahnya. Dengan mencantumkan sumber siaran pers dari Institut Informasi Independen novel tersebut ingin menunjukkan bahwa informasi yang disampaikan bersifat objektif dan tidak berada dalam tekanan pihak yang berkepentingan.

\section{Pemberontakan Pemerintahan Revolu- sioner Republik Indonesia (PRRI)}

Peristiwa sejarah yang berhubungan dengan pemberontakan Pemerintah Revolusioner Republik Indonesia (PRRI/ Permesta) dalam novel Cerita Cinta Enrico digunakan untuk menggambarkan sejarah kelahiran tokoh utama (Enrico). Enrico diceritakan sebagai anak seorang prajurit (Letda Irsad) yang dilahirkan bersamaan dengan waktu pemberontakan tersebut terjadi, 15 Februari 1958 di Padang.

Pemberontakan Pemerintah Revolusioner Republik Indonesia (PRRI/Permesta) didahului dengan pembentukan dewan- dewan di beberapa daerah di Sumatera, antara lain Dewan Banteng di Sumatera Barat oleh Letnan Kolonel Achmad Husein (20 Desember 1956), Dewan Gajah di Medan oleh Kolonel Maludin Simbolon (22 Desember 1956) dan Dewan Manguni di Manado oleh Letnan Kolonel Ventje Sumuai (18 Februari 1957). Tanggal 101958 didirikan organisasi yang bernama Gerakan Perjuangan Menyelamatkan Negara Republik Indonesia yang diketuai oleh Letnan Kolonel Achamad Husein. Gerakan Husein ini akhirnya mendirikan PRRI (Pemerintah Revolusioner Republik Indonesia) yang berkedudukan di Bukittinggi dengan Syafruddin Prawiranegara sebagai pejabat presiden (Kahin, 2005:101). Permesta (Perjuangan Rakyat Semesta) pada hari berikutnya mendukung dan bergabung dengan PRRI sehingga gerakan bersama itu disebut PRRI/Permesta. Permesta yang berpusat di Manado tokohnya adalah Letnan Kolonel Vantje Sumual, Mayor Gerungan, Mayor Runturambi, Letnan Kolonel D.J. Samba, dan Letnan Kolonel Saleh Lahade.

Dalam novel Cerita Cinta Enrico diceritakan kelahiran tokoh Enrico tepat pada hari pemberontakan PRRI terjadi, seperti tampak pada kutipan berikut.

Bentukku meramalkan bentuk revolusi bagi ayahku. Sebuah revolusi dengan kaki-kaki kurus. Ya, sebuah pemberontakan yang lahir pada tanggal 15 Februari 1958 di Padang adalah pemberontakan berkaki kurus. Saat dokter dan perawat telah meninggalkan mereka berdua, Irsad mengajak istrinya bicara mengenai hal itu.

"Kamu sudah dengar? Revolusi sudah diumumkan."

Istrinya mengangguk lemah.

....

Esoknya aku dibawa masuk ke belantara Sumatra. Aku menjadi bayi gerilya.

(Utami, 2012: 21-22)

Seperti yang terjadi dalam sejarah Indonesia, pemberontakan PRRI akhirnya dapat digagalkan oleh pasukan Kolonel Ahmad Yani. 
Sekarang marilah kita bayangkan apa yang terjadi di pulau Jawa. Ketika Kolonel Ahmad Yani (yang kelak menjadi "Pahlawan Revolusi") memimpin pasukan untuk menghancurkan pemberontakan PRRI dalam operasi yang dinamakan Operasi 17 Agustus, seluruh keluarga ayah dan ibuku geger....

(Utami, 2012:22)

Letda Irsad berbaris bersama seluruh gerilyawan, yang pada hari itu tidak bisa lagi menyebut diri mereka pasukan revolusi. Mereka adalah pasukan pemberontak, seperti nama yang diberikan Jawa kepada mereka. Revolusi berkaki kurus itu telah sepenuhnya menjadi pemberontakan setengah hati. Irsad tetap mencoba berdiri dengan sikap tegap seutuhnya, dengan kehormatan penuh, meskipun hatinya hancur ketika perwira pasukan Yani melucuti tanda pangkatnya....

(Utami, 2012:27)

Dalam novel Cerita Cinta Enrico peristiwa pemberontakan PRRI digunakan untuk menceritakan asal usul kelahiran tokoh Enrico. Yamin (2009:1) mengemukakan bahwa munculnya Pemerintah Revolusioner Republik Indonesia (PRRI) adalah sebagai akumulasi dari kekecewaan rakyat di daerah terhadap pemerintah pusat di Jakarta. Kekecewaan yang diakibatkan oleh sentralisasi kekuasaan dan memunculkan kesenjangan pembangunan di segala bidang antara pusat dan daerah, pembangunan di daerah terutama di Sumatera Tengah. PRRI diproklamirkan oleh Ahmad Husein di Padang pada tanggal 15 Februari 1958 dan mendapat sambutan dan dukungan penuh dari Perjuangan Semesta (PERMESTA) di Sulawesi. Sejumlah tokoh nasional baik sipil maupun militer juga memberikan dukungan dan ikut bergabung dengan PRRI di Sumatera Barat, antara lain M. Natsir, Syafruddin Prawiranegara, Burhanuddin Harahap, M. Syafe'i, Kolonel Dahlan Djambek, Kolonel Mauludin Simbolon dan Letnan Kolonel Ahmad Husein (Zed, 2001:274).
Walaupun kemudian oleh pemerintah RI perjuangan PRRI dianggap sebagai pemberontakan yang berhasil ditumpas oleh pemerintah, namun kalau dipahami latar belakang timbulnya PRRI adalah karena kekecewaan terhadap sentralisasi kekuasaan dan pembangunan yang tidak merata. Oleh karena itu, dengan mengangkat kembali perstiwa tersebut dalam novel Cerita Cinta Enrico dapat dimaknai bahwa rakyat yang ada di daerah, dengan dipimpin oleh para pejuang yang ada di daerah pada dasarnya tidak akan tinggal diam dengan adanya ketidakadilan dalam melaksanakan pembangungunan daerah.

\section{Demonstrasi Mahasiswa ITB dan Pener- bitan Buku Putih Perjuangan Mahasiswa 1978}

Selain peristiwa PRRI yang dihubungankan dengan asal usul kelahiran tokoh Enrico, dalam novel Cerita Cinta Enrico juga digambarkan peristiwa sejarah yang berhubungan dengan gerakan mahasiswa Indonesia mengritisi pemerintah pada masa Orde Baru. Setelah lulus SMA di Padang, Enrico melanjutkan sekolah (kuliah) di Institut Teknologi Bandung (ITB) pada tahun 1977. Pada 16 Januari 1978, Enrico bersama-sama dengan mahasiswa lainnya mengadakan demonstrasi untuk menolak pengangkatan kembali Soeharto sebagai presiden.

Pada pagi harinya, mahasiswa telah memasang kain merah besar bertuliskan "Dewan Mahasiswa ITB tak menginginkan Saudara Soeharto terpilih kembali sebagai Presiden RI". Spanduk menyala itu dibentangkan untuk menyambut Sidang Umum MRP 1978, yang sudah pasti akan memilih Jenderal Soeharto lagi.

Kami tahu bendera itu akan segera diturunkan beberapa menit saja setelah dipasang. Tapi tidak apa, toh pernyataan itu akan menjadi berita. Media akan memuatnya dan seluruh Indonesia akan menjadi tahu bahwa tidak semua orang ingin dia menjadi pemimpin lagi. Seluruh 
Indonesia akan jadi tahu bahwa ada yang berani bersuara. Tapi kami tidak terlalu menduga bahwa pembalasannya akan seperti ini.

Aku tiba di kampus ketika spanduk itu sudah direnggut. Mahasiswa mengadakan rapat dan dalam rapat itu ada yang nyampaikan berita bahwa kampus akan diduduki tentara. Bukan polisi, melainkan Angkatan Darat - yang paling berkuasa di antara angkatan lain....

Apapun kami memutuskan untuk mempertahankan kampus. Dengan cara berbaring di jalan di pintu masuk. Lewati dulu mayat kami sebelum kau kuasai ITB. Jika panser itu memaksa, mereka akan masuk dengan melindas mati mahasiswa. Kami akan jadi tameng hidup, bukan hanya bagi kampus ITB. Kampus itu kini adalah simbol akal sehat, lambang ketidaktundukan pada kekuasaan yang telah korup. Aku tak berpikir ulang. Tak ada satu pun di antara kami yang berpikir ulang. Sebab kami memperjuangkan cita-cita luhur.

(Utami, 2012: 134)

Peristiwa yang diceritakan dalam novel tersebut dapat dilacak dalam catatan perjalanan aktivitas mahasiswa ITB (http://km.itb.ac.id/site/?p=102) sebagai berikut.

16 Januari 1978 Apel bersama 2000 mahasiswa ITB dipimpin Ketua Umum Heri Akhmadi menyatakan Tidak Mempercayai dan Tidak Menginginkan Soeharto Kembali Sebagai Presiden Republik Indonesia. Penerbitan Buku Putih Perjuangan Mahasiswa 1978. Pembuatan buku putih ini dimotori oleh Rizal Ramli, Ketua Dewan Mahasiswa. Penerbitan buku putih ini juga didukung beberapa intelektual kampus seperti Prof. Iskandar Alisjahbana (Rektor ITB) dan Prof. Slamet Iman Santoso (mantan Dekan Fakultas Psikologi $\mathrm{UI})$.

21 Januari dan 9 Februari 1978 Kampus diserbu dua kali dan diduduki militer 6 bulan lamanya. Mahasiswa lama dikumpulkan di lapangan basket dan diusir, hanya mahasiswa angkatan 1978 yang boleh berkuliah. Terjadi penembakan gelap di rumah Rektor ITB Prof. Iskandar.
Laksusda Jawa Barat memanggil Heri Akhmadi, Rizal Ramli, Indro Tjahjono, Al Hilal Hamdi, dan Ramles Manampang Silalahi untuk kemudian diadili dan dipenjara. Normalisasi Kehidupan Kampus diberlakukan, DM se-Indonesia dibubarkan, pemerintah mengajukan konsep SMPT (Senat Mahasiswa Perguruan Tinggi) sebagai pengganti Dewan Mahasiswa, namun ditolak karena terlalu kuatnya intervensi pemerintah dan birokrasi kampus pada organisasi tersebut.

1979 Pembentukan Badan Koordinasi Kemahasiswaan (BKK) sebagai organ operasional kebijakan NKK disikapi dengan penolakan mahasiswa ITB. Akibatnya lembaga ini tidak pernah jelas eksistensinya.

1979-1982 Tekanan kuat dari Rektorat untuk membubarkan DM dengan surat ancaman DO untuk setiap Ketua Umum terpilih. Buku Biru diterbitkan sebagai lanjutan penerbitan Buku Putih.(http:// km.itb.ac.id/site/?p=102).

Dengan menggunakan perspektif new historicism, maka sejumlah peristiwa sejarah yang terdapat dalam novel-novel karya Ayu Utami tersebut pada dasarnya hadir untuk mempertanyakan kembali kebenaran sejarah yang telah dicatat sebelumnya. New Historicism memahami setiap segi realitas tertuang dalam teks dan struktur sosial yang ditentukan oleh "praktik diskursif" yang dominan, sehingga harus dipertanyakan kembali kebenarannya.

Dari lima buah peristiwa sejarah yang digambarkan dalam keempat novel karya Ayu Utami tampak bahwa peristiwa-peristiwa tersebut dilakukan oleh kelompok (kaum) marginal. Mereka adalah kaum buruh yang melakukan demonstraksi dan pemogokan buruh di Medan, prajurit dan rakyat yang dituduh terlibat dalam gerakan 30 September, rakyat yang prodemokrasi yang menolak otoritarian pemerintah Orde Baru, angkatan bersenjata yang ada di daerah yang kecewa dengan sentralisasi pemerintah pusat dan ketidak- 
merataan pembangunan, dan mahasiswa (ITB) yang menolak pemimpin (presiden) yang otoriter dan korup).

Dalam sejarah resmi versi pemerintah selama ini kelompok-kelompok tersebut diberi label sebagai kaum pemberontak yang mengacaukan keteraturan dan keamanan negara. Oleh karena itu, keberadaannya harus dibasmi, dilarang eksistensinya. Para pelakunya harus ditangkap dan dihukum. Melalui novel-novel tersebut, peristiwa-peristiwa tersebut diberi ruang dan suara untuk mengakui keberadaannya, bukan sebagai pihak yang melakukan pemberontakan untuk mengacau keteraturan dan kedamaian, tetapi sebagai pihak yang berjuang untuk mengakhiri otoritarian dan ketidakadilan.

\section{SIMPULAN}

Dari penelitian yang telah dilakukan dapat ditarik beberapa kesimpulan berikut. Pertama, peristiwa sejarah sosial politik yang terdapat dalam novel-novel karya Ayu Utami adalah (a) di Medan 1 Maret sampai dengan 16 April 1994, (b) Gerakan 30 September 1965, (c) tragedi 27 Juli 1996 di Jakarta atau penyerangan kantor DPP Partai Demokrasi Pro Megawati oleh massa pendukung Suryadi, (d) pemberontakan Pemerintahan Revolusioner Republik Indonesia (PRRI), 15 Februari 1958 di Padang, (e) demonstrasi Mahasiswa ITB dan penerbitan Buku Putih Perjuangan Mahasiswa 1978 untuk menolak pengangkatan kembali Soeharto sebagai presiden RI.

Kedua, peristiwa tersebut direpresentasikan dalam bagian yang integral dalam peristiwa yang dialami oleh tokohtokoh dalam novel. Artinya, peristiwa sejarah yang berasal dari peristiwa nyata dikontekstualkan dalam fiksi yang ditulis pengarang.

Ketiga, dalam perspektif new historicism, sejumlah peristiwa sejarah sosial politik yang terdapat dalam novel-novel karya Ayu Utami pada dasarnya hadir untuk mempertanyakan kembali kebenaran sejarah yang telah dicatat sebelumnya. Pemerintah Orde Baru dianggap telah melakukan tindakan represi yang berlebihan dan melanggar HAM dalam mengatasi demonstrasi dan pemogokan buruh di Medan, kerusuhan 27 Juli 1996 di Jakarta, dan demonstrasi mahasiswa ITB, 1978 yang menolak pengangkatan kembali Soeharto sebagai presiden. Keterlibatan PKI dan Pasukan Cakrabirawa juga dipertanyakan dalam peristiwa G30S, karena banyak pihak yang sebenarnya ikut berperan dalam peristiwa tersebut, terutama dari kalangan TNI. Dalam kasus pemberontakan PRRI, peristiwa tersebut dilihat sebagai bentuk protes menentang terhadap pemerintah pusat (Jakarta). Sikap mempertanyakan kebenaran sejarah tersebut sesuai dengan persp new historicismmemahami setiap segi realitas tertuang dalam teks dan struktur sosial yang ditentukan oleh "praktik diskursif" yang dominan, sehingga harus dipertanyakan kembali kebenarannya.

\section{UCAPAN TERIMA KASIH}

Artikel ini diangkat dari hasil penelitian yang dilaksanakan pada tahun 2011 dengan anggaran DIPA FBS UNY. Ucapan terimakasih disampaikan kepada Universitas Negeri Yogyakarta yang telah memfasilitasi penelitian ini. Selanjutnya ucapan terimaksih diucapkan kepada reviewer yang telah membaca, mengoreksi dan memberi masukan terhadap artikel ini.

\section{DAFTAR PUSTAKA}

Barry, Peter. 2010. Begening Theory, an Introductioan to Literary and Cultural Theory.Terjemahan Harviyah Widyawati dan Evi Setyarini. Yogyakarta: Jalasutra.

Budianta, Melani. 2006. “Budaya, Sejarah, dan Pasar, New historicism dalam Perkembangan Kritik Sastra," dalam Susastra, Jurnal Ilmu Sastra dan Bu- 
daya. Jakarta: Himpunan Sarjana Kesusastraan Indonesia.

Damono, Sapardi Djoko. 1989. Sosiologi Sastra Sebuah Pengantar. Jakarta: Pusat Pembinaan dan Pengembangan Bahasa.

Kahin, Audrey. 2005. Dari Pemberontakan ke Integrasi Sumatera Barat dan Politik Indonesia 1926-1998. Jakarta: Yayasan Obor Indonesia.

Kayam, Umar. 1999. Para Priyayi. Jakarta: Gramedia.

Katopo, dkk. 1999. Menyingkap Kabut Halim 1965. Jakarta: Pustaka.

Luhulima, James. 2007. “Menyingkap Dua Hari Tergelap di Tahun 1965. Melihat Peristiwa G30S dengan Perspektif Lain". Jakarta: Kompas.

Yamin, M. 2009. Dewan Banteng Contra Neo Ningrat. Jakarta: LPPM Tan Malaka.
Ricklefs. H.C. 1991. Sejarah Indonesia Modern, Diterjemahkan dalam bahasa Indonesia oleh Dharmono Hardjowidjono. Yogyakarta: Gadjah Mada University Press.

Rusli, Marah. 1920. Sitti Nurbaya. Jakarta: Balai Pustaka.

Suara Pembaruan, Senin 2 Mei 1994. "Demonstrasi dan Pemogokan Buruh di Medan."

Utami, Ayu. 1998. Saman. Jakarta: Gramedia.

Utami, Ayu. 2001. Larung. Jakarta: Gramedia.

Utami, Ayu. 2010. Manjali dan Cakrabirawa. Jakarta: Gramedia.

Utami, Ayu. 2012. Cerita Cinta Enrico. Jakarta: Gramedia

Zed, Mestika dan Hasril Chaniago, 2001. Perlawanan Seorang Pejuang Biografi Kolonel Ahmad Husein.Jakarta: Pustaka Sinar Harapan. 